\title{
UPAYA PENINGKATAN MUTU PENDIDIKAN SEKOLAH MENENGAH KEJURUAN MELALUI PENGEMBANGAN PROFESIONALISME GURU
}

\author{
Cok Istri Raka Marsiti \\ Jurusan Pendidikan Kesejahteraan Keluarga \\ Universitas Pendidikan Ganesha
}

\begin{abstract}
Vocational High School Quality Improvement Through Teacher Professional Development. Education is a key in improving quality of the nation. Human resource development is a strategic attempt that should be carried out by the government. Professional teacher is a whole building that covers thinking and acting in learning activities. As a consequence evaluation instrument of competency is a building unit that can be used to measure teachers competency. Professional teacher requires professional in teaching and training. Teachers roles are to generate learning activity, however, they face problems in executing their tasks, community perceptions on teachers, and teachers prosperity. Therefore, regeneration of teachers and continued development of human resource are answering these problems.
\end{abstract}

Kata kunci: Mutu Pendidikan, SMK, profesionalisme guru.

\section{PENDAHULUAN}

Pembangunan nasional dalam bidang pendidikan diarahkan untuk menunjang upaya peningkatan mutu sumber daya manusia yang beriman dan bertakwa kepada Tuhan Yang Maha Esa, berakhlak mulia, sehat berilmu, capak, kreatif, mandiri dan menjadi warga negara yang demokratis, serta bertanggung jawab. Hal ini sejalan dengan yang diamanatkan dalam Undang-Undang Nomor 20 Tahun 2003 tentang Sistem Pendidikan Nasional (UUSPN), Bab II Pasal 3.

Sampai saat ini persoalan pendidikan yang dihadapi bangsa Indonesia adalah rendahnya mutu pendidikan, pada setiap jenjang dan satuan pendidikan, khususnya pendidikan dasar dan menengah. Berbagai upaya untuk meningkatkan mutu pendidikan tersebut telah terus dilakukan, mulai dari berbagai pelatihan untuk meningkatkan kualitas guru, penyempurnaan kurikulum secara periodik, perbaiki sarana dan prasarana pendidikan, sampai dengan meningkatan manajemen berbasis sekolah. Semakin baik 
pendidikan suatu bangsa semakin baik pula kualitas bangsa tersebut. Secara faktual pendidikan menggambarkan aktivitas sekelompok orang seperti guru dan tenaga kependidikan lainnya melaksanakan pendidikan untuk orang-orang muda dengan bekerjasama dengan orang-orang yang berkepentingan.

Mutu pendidikan merupakan masalah yang dijadikan agenda utama untuk diatasi dalam kebijakan pembangunan pendidikan, karena hanya dengan pendidikan yang bermutu akan diperoleh lulusan bermutu yang mampu membangun diri, keluarga, masyarakat, bangsa dan negara. Standar Nasional Pendidikan yang ditetapkan dengan Peraturan Pemerintah No. 19 Tahun 2005, dan merupakan penjabaran lebih lanjut dari Undang-Undang Sistem Pendidikan Nasional, telah menggariskan ketentuan minimum bagi satuan pendidikan formal agar dapat memenuhi mutu pendidikan.

Sejalan dengan peningkatan mutu pendidikan telah pula digariskan kebijakan mengenai pemerataan kesempatan pendidikan yang bukan hanya menambah fasilitas pendidikan secara kuantitatitif, melainkan juga keseluruah komponen secara kualitatif. Dengan kata lain adalah pemerataan kesempatan pendidikan yang bermutu pada semua jalur, jenis dan jenjang pendidikan. Termasuk dalam kebijakan ini adalah pengembangan pendidikan kejuruan (SMK).

Pendidikan kejuruan merupakan program strategis untuk menye-diakan tenaga kerja tingkat menengah. Namun kenyataan menunjukkan bahwa program ini kurang menarik perhatian kebanyakan orangtua dan anak-anaknya, terutama dari golongan ekonomi menengah ke atas. Demikian juga siswa yang prestasi akademiknya tinggi cenderung tidak memilih pendidikan kejuruan, melainkan pendidikan umum yang lebih leluasa untuk memasuki jenjang pendidikan tinggi. Usaha untuk menarik minat masyarakat termasuk remaja lulusan pendidikan dasar, untuk memasuki sekolah kejuruan memang perlu dilakukan dengan sungguh-sungguh. Usaha tersebut tidak cukup hanya dengan melakukan promosi dengan misalnya mencetak dan menyebarkan informasi. Tetapi harus terlebih dahulu ditunjukkan hasil yang bermutu dan berdayaguna.

Berdasarkan latar belakang tersebut, pengkajian ini dimaksudkan untuk mendeskripsikan dan kemudian menganalisis apakah realitas lapangan mengenai 
perkembangan pendidikan kejuruan sudah sesuai dengan pendapat para pakar dalam bidang yang bersangkutan, dengan kebutuhan di lapangan kerja, dan dengan hasil kajian pustaka yang dilakukan. Obyek utama kajian ini adalah sekolah kejuruan yang terutama menyelenggarakan program pendidikan yang mengarah kepada pemberdayaan perempuan, yaitu program tata busana, tata rias, tata boga, dan jasa pariwisata.

Proses pembelajaran merupakan suatu sistem. Dengan demikian, pencapaian standar proses pembelajaran untuk meningkatkan mutu pendidikan dapat dimulai dari menganalisis setiap proses pembelajaran. Begitu banyak komponen yang mempengaruhi masalah mutu pendidikan, namun demikian, tidak mungkin upaya peningkatan kualitas atau mutu pendidikan dilakukan setiap komponen secara serempak. Hal ini selain komponen-komponen itu keberadaannya terpencar, jiga kita sulit menentukan kadar kepengaruhan setiap komponen. Namun demikian, komponen yang selama ini dianggap sangat mempengaruhi proses pendidikan adalah komponen guru.

Selama ini guru adalah sosok yang sering dijadikan kambing hitam atas bobroknya nilai pendidikan, kegagalan itu selalu ditujukan pada guru, bahkan sumpah serapahpun akan bermunculan. Berdasarkan hasil pemantuan dan wawancara dilapangan banyak hambatan yang dialami guru diantaranya guru tidak bisa menerapkan metode yang tepat dalam proses belajar mengajar, tidak bisa berbuat banyak karena daerah terpencil, sarana dan prasarana yang tidak mendukung kelancaran proses belajar mengajar, tidak mampu menerapkan $\mathrm{KBK}$, tidak bisa membuat alat peraga yang inovatif.

Profesionalisme guru sering dikaitkan dengan tiga faktor yang cukup penting, yaitu kompetensi, sertifikasi, dan tunjangan profesi. Ketiga faktor tersebut diprediksi mempengaruhi kualitas pendidikan. Sertifikasi erat kaitannya dengan proses belajar, sehingga tidak bisa diasumsikan mencerminkan kompetensi yang unggul sepanjang hayat. Pasca sertifikasi seyogyanya merupakan tonggak awal bagi guru untuk meningkatkan kompetensi dan profesionalisme secara kontinyu. Secara preskriptif, dukungan kompetensi manajemen, strategi pemberdayaan, supervisi pengembangan, dan penelitian tindakan kelas merupakan dimensi-dimensi teoretis alternatif untuk meningkatkan kompetensi dan profesionalisme guru. Keempat dimensi teoretis tersebut 
berlandaskan pada filosofi humanistik, bahwa pada dasarnya guru dapat meningkatkan profesionalismenya secara mandiri. Dimensi-dimensi teoretis tersebut berperan sebagai fasilitas dan pijakan bagi guru untuk meningkatkan komitmen dan kesadaran berbasis refleksi diri dalam rangka meningkatkan profesionalismenya.

\section{GURU PROFESIONAL}

Guru sebagai tugas profesi adalah suatu pekerjaan yang menuntut keahlian tertentu. Pekerjaan atau jabatan ini tidak bisa dikerjakan oleh sembarang orang yang bukan ahlinya. Orang yang mampu mengerjakan suatu tugas atau jabatan sesuai dengan tuntutan profesinya. Guru yang profesional dituntut dapat melaksanakan tugas profesi, yaitu: mendidik, mengajar dan melatih. Guru tidak hanya mengemban tugas profesi, melainkan juga dituntut melaksanakan tugas kemanusiaan, yaitu sebagai orang tua kedua bagi anak didik dan transformasi diri di dalam kelas dan masyarakat. Guru sebagai tugas masyarakat berdasarkan UUD 1945 yaitu mencerdaskan kehidupan bangsa, maka guru dituntut mampu melaksanakan tugas kemasyarakatan dengan mendidik, mengajarkan masyarakat menjadi warga negara yang baik dan bertanggungjawab.

Kajian tentang sekolah menegah Kejuruan yang dilakukan oleh tim kajian staf ahli Mendiknas bidang mutu Pendidikan yang diketuai oleh Harina Yuhetty, menghasilkan beberapa kajian diantaranya adalah: untuk menghasilkan lulusan yang siap pakai, mandiri atau mampu berwirausaha SMK perlu melakukan usaha-usaha baik dibidang pengembangan kurikulum, tenaga kependidikan, dengan menyertakan DUDI dalam kegiatan sekolah. Pihak DUDI menyarankan agar SMK menambah guru yang sesuai dengan bidangnya dan perlu meningkatkan kompetensi dan wawasan agar sesuai dengan perkembangan ilmu pengetahuan dan teknologi yang relevan dengan bidang keahlian yang diampunya.

Dari uraian di atas diketahui bahwa guru sebagaio tenaga kependidikan mendapat porsi tugas sangat berat tugas yang diamanatkan kepada seorang guru untuk meningkatkan mutu pendidikan. Di samping itu masih ada lagi tugas yang harus 
dilakoni guru sebagai manusia biasa di dalam keluarga dan masyarakat yang sama beratnya dengan tugas profesi, kemanusiaan dan masyarakat.

Sebuah profesi merupakan pekerjaan mental yang mempersyaratkan pendidikan tinggi dalam bidang keahlian tertentu, minimal 4 tahun sesudah SLA. Dengan demikian sebuah profesi akan didukung oleh empat pilar utama, yaitu: knowledge, ability, academic preparation, and recognition. Secara khusus, kompetensi profesional pendidik dipayungi oleh UU No. 14/tahun 2005. Kinerja guru sebagai pendidik professional, menjadi sebuah peluang untuk mendapatkan pengakuan dalam jabatan profesi, yang dilindungi hukum dan disertai peningkatan kesejahteraan. Dengan demikian, akan mendorong tanggung jawab dan komitmen profesional dalam meningkatkan mutu pendidikan nasional.

Dalam UU No. 14/Tahun 2005 disebutkan empat kompetensi yang melandasi kinerja setiap pendidik profesional, yaitu: (1) penguasaan kemampuan terkait dengan tanggung jawab dalam penyelenggaraan proses pembelajaran (kompetensi pedagogik), (2) penguasaan bidang ilmu yang akan diajarkan kepada siswanya, (kualifikasi akademik), (3) kemampuan berinteraksi dengan lingkungan masyarakat, dan (4) kemampuan menampilkan integritas pribadi terpuji yang patut diteladani.

Undang-undang Sistem Pendidikan Nasional nomor 20 tahun 2003 pasal 1 ayat 5 , menyebutkan bahwa tenaga kependidikan adalah "anggota masyarakat yang mengabdikan diri dan diangkat untuk menunjang penyelenggaraan pendidikan". Ayat 6 pasal yang sama disebutkan bahwa tenaga kependidikan adalah "mereka yang berkualifikasi sebagai guru, dosen, konselor, pamong belajar, widyaiswara, tutor, instruktur, fasilitator, dan sebutan lain yang sesuai dengan kekhususannya, serta berpartisipasi dalam penyelenggaraan pendidikan". Selanjutnya pasal 39 ayat 2 menyatakan bahwa "pendidik merupakan tenaga profesional yang bertugas merencanakan dan melaksanakan proses pembelajaran, menilai hasil pembelajaran, melakukan pembimbingan dan pelatihan, serta melakukan penelitian dan pengabdian kepada masyarakat, terutama bagi pendidik pada perguruan tinggi. 
Kompetensi tenaga kependidikan terutama guru bersifat kompleks. Kompetensi merupakan satu kesatuan utuh yang menggambarkan potensi, pengetahuan, keterampilan, sikap, dan nilai yang dimiliki guru terkait dengan profesinya, terkait dengan kemampuan mengaktualisasikan atau mewujudkan dalam bentuk perilaku, tindakan atau kinerja untuk menjalankan profesi. Kualifikasi profesional merupakan bentuk perwujudan kompetensi yang dimiliki guru.

Kompetensi mengandung unsur-unsur yang dapat ditampilkan dan yang tidak dapat ditampilkan. Manifestasi yang dapat ditampilkan dan nampak secara lahiriah disebut performance. Seseorang dapat menunjukkan performance apabila memiliki kompetensi. Kompetensi guru dapat dilihat dari penampilannya ketika mengajar.

Untuk dapat menjadi guru yang profesional dalam mengelola pembelajaran (sebagai representasi pelaksanaan tugas dan fungsinya) dituntut memiliki penguasaan isi bidang studi, pemahaman karakteristik peserta didik, melakonkan pembelajaran yang mendidik, dan potensi pengembangan profesionalisme dan kepribadian (Depdiknas, 2002; dan Depdiknas, 2004). Keempat rumpun standar kompetensi guru tersebut dapat diuraikan secara singkat sebagai berikut.

\section{Penguasaan Bidang Studi}

Indikator penguasaan bidang studi ini meliputi pe-mahaman karakteristik dan substansi ilmu sumber bahan ajaran, pemahaman disiplin ilmu yang bersangkutan dalam konteks yang lebih luas, penggunaan metodologi ilmu yang bersangkutan untuk memverifikasikan dan memantapkan pemahaman konsep yang dipelajari, dan penyesuaian substansi ilmu yang bersangkutan dengan tuntutan dan ruang gerak kurikuler, serta pemahaman tata kerja dan cara pengamanan kegiatan praktik. Hal ini menjadi penting dalam memberikan dasar-dasar pembentukan kompetensi dan profesionalisme guru di sekolah. Dengan menguasai isi bidang studi yang diajarkan guru dapat memilih, menetapkan, dan alternatif strategi berinteraksi dari berbagai sumber belajar yang gayut dengan kompetensi lulusan yang akan dicapai dalam pembelajaran. 


\section{Pemahaman Tentang Peserta Didik}

Pemahaman tentang karakteristik peserta didik meliputi pemahaman berbagai ciri peserta didik, pemahaman tahap-tahap perkembangan peserta didik dalam berbagai aspek dan penerapannya (aspek kognitif, aspek afektif, Aspek Psikomotorik) dalam mengoptimalkan perkembangan dan pem-belajaran peserta didik. Guru dalam melaksanakan tugas dan fungsinya dihadapkan pada suatu komunitas individu yang memiliki variasi karakteristik yang sebanding dengan jumlah individu dalam komunitas tersebut. Pemahaman terhadap aspek ini oleh para guru menjadi prasyarat dapat melakukan strategi pembimbingan, pelatihan yang sesuai dengan karkateristik individu pebelajar yang difasilitasi.

\section{Melakukan Pembelajaran yang Mendidik}

Penguasaan pembel-ajaran yang mendidik terdiri atas pemahaman konsep dasar proses pendidikan dan pembelajaran bidang studi yang bersangkutan, serta penerapannya dalam pelaksanaan dan pengembangan proses pembelajaran yang mendidik. Ciri pembelajaran yang men-didik adalah guru dalam upaya memfasilitasi perkembangan potensi individu secara optimal dan bersinergi antara pengembangan potensi pada ranah tertentu (kognitif, afektif, psikomotorik).

\section{Pengembangan Kepribadian dan Keprofesionalan}

Pengembangan kepri-badian dan keprofesionalan mencakup pengembangan intuisi keagamaan, intuisi ke-bangsaan yang berkepribadian, sikap dan kemampuan mengaktualisasi diri, serta sikap dan kemampuan mengembangkan profesionalisme kependidikan. Guru dalam melaksanakan tugasnya selalu bersikap terbuka, kritis, dan skeptis untuk mengaktu-alisasi pengusaan isi bidang studi, pemahaman karaktersitik peserta didik, dan mela-konkan pembelajaran yang mendidik. Di samping itu, guru dalam melaksanakan tugas perlu dilandasi sifat ikhlas dan bertanggungjawab atas profesi yang menjadi pilihan, sehingga berpotensi menumbuhkan kepribadian yang tangguh dan memiliki jati diri.

Untuk menumbuhkan kompetensi antar guru, diperlukan sistem penggajian yang tepat. Perbedaan gaji antara guru yang berprestasi dengan guru yang tidak berprestasi 
harus ada. Guru yang prestasinya bagus diberikan penghargaan insentif. Selama ini gaji mereka sama rata, sehingga tidak tumbuh keinginan diantara mereka untuk berprestasi. Pemahaman berprestasi atau tidak, kreatif atau tidak kreatif bayarannya tetap sama. Kemudian, idealnya gaji guru sekarang harus memadai jika dibandingkan dengan gaji pegawai "kantoran" yang lain, seperti BUMN, BUMD dan instansi pemerintah lainnya.

Profesionalisme guru menjadi sebuah wacana yang sangat menarik. Isu ini bahkan berkembang menjadi sebuah komoditi dan merupakan peluang bisnis bagi sekelompok masyarakat (khususnya mereka yang tertarik dengan penyelenggaraan Diklat, Seminar, dsb). Betapa tidak, setiap sertifikat keterlibatan guru dalam berbagai kegiatan ilmiah, akan menjadi sebuah bukti fisik untuk mendapatkan nilai dalam portofolio. Hal ini memicu para guru berlomba mendapatkan sertifikat itu sebanyak-banyaknya, walaupun mereka harus mengeluarkan sejumlah uang sebagai tanda kontribusi. Padahal, sebelum terbitnya kebijakan proses sertifikasi melalui penilaian portofolio, forum-forum di atas hampir tidak diminati oleh para guru, walaupun ditawarkan secara gratis dan tidak dipungut biaya kontribusi. Demikian pula tawaran mendapatkan piagam penghargaan semakin menjamur. Modus penghargaan sangat bervariasi. Setiap penghargaan diberikan dalam sebuah acara seremonial yang bergengsi, dan berlangsung di hotel-hotel berbintang. Namun ujung-ujungnya, kontribusi finansial juga.

Di lain pihak, kebijakan sertifikasi profesi bagi para pendidik (baca: guru dan dosen) tetap menjadi sebuah peluang untuk menampilkan kinerja profesional, yang akan memicu semangat dan tanggung jawab dalam meningkatkan mutu pendidikan nasional. Di tangan para pendidik proses pembelajaran akan berlangsung secara bermutu ataupun tidak. Oleh karena itu, sangatlah tepat ketika pemerintah semakin menunjukkan kepedulian terhadap peningkatan professionalisme pendidik. Hal ini dibuktikan dengan lahirnya berbagai produk hukum yang menjadi landasan bagi pengakuan jabatan pendidik sebagai sebuah profesi. 
Upaya penjaminan mutu guru agar tetap memenuhi standar kompetensi yang telah diuraikan di atas, diperlukan adanya suatu mekanisme yang memadai. Mekanisme penjaminan mutu guru ini tentunya dikembangkan berdasarkan pengkajian yang komprehensif untuk menghasilkan landasan konseptual dan landasan empirik. Kegiatan penjaminan mutu guru ini dilakukan melalui sistem sertifikasi kompetensi guru. Sertifikasi adalah prosedur yang digunakan oleh pihak ketiga untuk memberikan jaminan tertulis bahwa sesuatu produk, proses, atau jasa telah memenuhi persyaratan yang ditetapkan (Nataamijaya, 2004). Sertifikasi kompetensi guru adalah prosedur yang digunakan oleh pihak yang berwenang untuk memberikan jaminan tertulis bahwa seseorang telah memenuhi persyaratan kompetensi sebagai guru yang di-tetapkan. Indikator perangkat instrumen sertifikasi kompetensi guru dikembangkan berdasarkan keempat standar kompetensi guru (penguasaan isi, pemahaman peserta didik, pembelajaran yang mendidik, dan kemampuan berkembang kepribadian dan profeionalisme) dengan disertai jabaran deskriptornya. Lembaga atau pihak yang menangani hal ini dapat berupa lembaga sertifikasi kompetensi guru, baik di dalam maupun di luar LPTK yang terakreditasi.

Sertifikasi kompetensi guru merupakan pemenuhan kebutuhan untuk meningkatkan kompetensi profesional guru. Oleh karena itu, proses sertifikasi dipandang sebagi bagian esensial dalam upaya memperoleh sertifikat kompetensi sesuai dengan standar yang telah ditetapkan. Dalam konteks ini Sertifikasi kompetensi guru merupakan proses uji kompetensi bagi colon atau guru yang ingin memperoleh pengakuan dan atau meningkatkan kompetensi atas bidang atau profesi yang dipilihnya. Repre-sentasi pemenuhan standar kompetensi yang telah ditetapkan dalam sertifikasi kompe-tensi adalah sertifikat kompetensi mengajar. Sertifikat ini sebagai bukti pengakuan atas kompetensi guru atau colon guru yang memenuhi standar untuk melakukan pe-kerjaan profesi guru pada jenis dan jenjang pendidikan tertentu.

Upaya melakukan sertifikasi kompetensi guru sesuai dengan amanat UU RI Nomor 20 Tahun 2003 Pasal 61 tentang Sisdiknas menyatakan bahwa sertifikat dapat berbentuk ijazah dan sertifikat kompetensi. Sertifikat dalam hal ini, bukan diinter- 
prestasikan sebagai sertifikat yang diperoleh melalui pertemuan ilmiah seperti seminar,diskusi panel, lokakarya, simposium. Namun, sertifikat kompetensi dalam konteks ini diperoleh dari penyelenggara pendidikan dan lembaga pelatihan setelah lulus uji kompetensi yang diselenggarakan oleh satuan pendidikan yang terakreditasi atau lembaga sertifikasi. Ketentuan ini bersifat umum, baik untuk tenaga kependidikan maupun non-kependidikan yang ingin memasuki profesi sebagai guru.

Profesionalisme pendidik harus didukung berbagai upaya dalam mewujudkan kinerja sesuai tuntutan profesi. Hal ini tentu saja akan menjadi sebuah peluang bagi pengembangan karier dan peningkatan kesejahteraan, namun dalam implementasinya akan muncul berbagai aspek yang menjadi tantangan dan bahkan menjadi kendala bagi tercapainya keinginan menjadi pendidik profesional.

Sebagai pendidik profesional dituntut kemampuan untuk menampilkan perilaku profesional yang dapat dibanggakan. Untuk itu, perlu dikembangkan berbagai model maupun strategi bagi pembinaan dan pengembangan karier dalam sebuah wadah profesi.

Selanjutnya adalah memberikan pemahamanan kepada masyarakat tentang pendapatan yang didapat dari hasil kerja sebagai seorang guru sangat memuaskan, idealnya gaji guru seimbang dengan pekerjaan. Guru tidak perlu berprofesi ganda karena hasil yang diperoleh dari kerjanya sebagai guru sudah mencukupi. Profil guruguru di daerah yang nota-benenya biaya hidup masih relatif terjangkau, dibandingkan dengan keadaan guru yang di tinggal di kota-kota besar dengan biaya hidup yang sangat tinggi. Pemenuhan kebutuhan mutlak diperlukan dan merupakan fitrah bagi manusia untuk mencari kesejahteraan dan kebutuhan hidupnya. Realitanya sekarang "Apakah semua guru di negara kita sudah terpenuhi kebutuhannya ?" Jawabannya sangat relatif guru yang sudah mapan bukan semata-mata diperoleh dari imbalan sebagai seorang guru, disisi lain ada guru yang keadaannya memprihatikan. Kebanyakan diantara mereka berprofesi ganda untuk menuhi taraf pemuasan hidupnya, bahkan ada diantara mereka mempertahankan hidup dari seleksi alam. Meningkatkan sumber daya guru adalah meningkatkan kesejahteraan guru seutuhnya, disinilah starting point pemberdayaan itu dilakukan. 


\section{KESIMPULAN}

Kompetensi mengandung unsur-unsur yang dapat ditampilkan dan yang tidak dapat ditampilkan. Manifestasi yang dapat ditampilkan dan nampak secara lahiriah disebut performance. Seseorang dapat menunjukkan performance apabila memiliki kompetensi. Kompetensi guru dapat dilihat dari penampilannya ketika mengajar. Empat rumpun kompetensi guru diantaranya yakni; penguasaan bidang studi, pemahaman peserta didik, melakukan pembelajaran yang mendidik dan pengembangan kepribadian dan keprofesionalan.

Profesionalisme pendidik merupakan sebuah peluang untuk meningkatkan kompetensi profesional dan peningkatan kesejahteraan. Namun di lain pihak, hal ini sekaligus menjadi tantangan bagi para pendidik, khususnya menyangkut tuntutan untuk selalu meningkatkan produktivitas dan beradaptasi dengan perubahan dalam merespons tantangan global terkait peningkatan mutu pendidikan.

Profesionalisme guru perlu didukung untuk dapat meningkatkan mutu pendidikan yang selama ini mendajadi permasalahan yang urgen dalam dunia pendidikan. Hal lain yang perlu kiranya mendapat perhatian bersama adalah kesejahteraan guru, hal inipun sebenarnya sudah tersirat dalam Undang-undang guru dan dosen. Sertifikasi guru bertujuan untuk memberikan tunjang profesi kepada para guru, dimana harapannya dengan tunjangan profesi tersebut kegiatan belajar mengajar akan menjadi lebih berkualitas, karena para tenaga pendidik sudah sejahtera serta implikasi akhirnya adalah kualitas pendidikan dalam hal ini mutu pendidikan akan menjadi lebih baik.

\section{DAFTAR PUSTAKA}

A. Mukhadis. 2008. Standar dan Kompetensi Representasi Penjaminan Mutu profesionalisme Guru Di Indonesia Pada Abad pengetahuan. Konaspi

Agung. 2009. Pengembangan Kompetensi Guru Dalam Upaya Meningkatkan Kemampuan Profesionalismenya.

Raflis, K., Soecipto. 2000. Profesi Keguruan. Jakarta: Reneka Cipta.

Rustiyah, N. K. 1986. Masalah Pengajaran Sebagai Suatu Sistem. Jakarta: PT Bina Aksara. 
Syaiful Sagala. 2005. Administrasi Pendidikan kontemporer. Bandung: Alfabeta

Taufik, M. 2006. Prakawah Candradimuka Cetak SDM Berkualitas. http//www.freelist.org/ archives/ppi/06-2006/msg00002.html (Diakses, 20 Juli 2008).

Wina Sanjaya. 2009. Kurikulum dan Pembelajaran: teori dan Praktik Pengembangan Kurikulum Tingkat Satuan pendidikan (KTSP). Jakarta: Kencana 